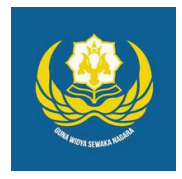

Jurnal Analogi Hukum

Journal Homepage: https://ejournal.warmadewa.ac.id/index.php/analogihukum

\title{
Mediasi Online sebagai Alternatif Penyelesaian Sengketa Hubungan Industrial pada Masa Pandemi Covid-19 di Indonesia
}

\author{
Dewa Putu Ade Wicaksana*, Anak Agung Sagung Laksmi Dewi dan Luh Putu Suryani \\ Universitas Warmadewa, Denpasar-Bali, Indonesia \\ *dewawicak01@gmail.com
}

\begin{abstract}
How To Cite:
Wicaksana, D, P, A., Dewi, A, A, S, L., Suryani, L, P. (2021). Mediasi Online sebagai Alternatif Penyelesaian Sengketa Hubungan Industrial pada Masa Pandemi Covid-19 di Indonesia. Jurnal Analogi Hukum. 3 (2). 177-182. Doi: https://doi.org/10.22225/ah.3.2.2021.177-182
\end{abstract}

\begin{abstract}
The massive spread of the Covid-19 pandemic has hampered the process of resolving conventional industrial relations disputes in Indonesia. Online mediation as an alternative dispute resolution forum that is capable of accommodating the interests of the parties according to the formal rules of industrial relations dispute settlement in collaboration with technology. The problems of this study are: 1. How is the arrangement of online mediation as an alternative to resolving industrial relations disputes during the COVID-19 pandemic in Indonesia; 2. How is the validity of the results of online mediation as an alternative to resolving industrial relations disputes during the COVID-19 pandemic. The research method used is a normative legal research method that examines legal norms substantially, based on a conceptual approach and a legal approach. The collection of legal materials using document study techniques. The results of this study indicate that the Law. No. 30 of 1999 and Law. No. 2 of 2004 has implicitly provided space for online mediation as an alternative instrument for resolving industrial relations disputes. Indonesia does not yet have a legal umbrella both formal and material that regulates "lex specialis" regarding online mediation as well as written agreements resulting from online mediation as an alternative to resolving industrial relations disputes during the COVID19 pandemic, does not yet have legally binding power, so it is still vulnerable to be violated by the parties.
\end{abstract}

Keywords: COVID-19 pandemic; dispute resolution; online mediation

\begin{abstract}
Abstrak-Penyebaran Pandemi Covid-19 yang masih menghambat proses penyelesaian sengketa hubungan industrial konvensional di Indonesia. Mediasi online hadir sebagai wadah alternatif penyelesaian sengketa yang dapat mengakomodir kepentingan para pihak sesuai kaidah formil penyelesaian sengketa hubungan industrial dan kemajuan di bidang teknologi. Permasalahan dari penelitian ini adalah: 1. Bagaimana pengaturan mediasi online sebagai alternatif penyelesaian sengketa hubungan industrial pada masa pandemi COVID-19 di Indonesia; 2. Bagaimana keabsahan hasil mediasi online sebagai alternatif penyelesaian sengketa hubungan industrial pada masa pandemi COVID-19. Metode penelitian yang digunakan adalah metode penelitian hukum normatif yang mengkaji norma hukum secara substansial, didasarkan pada pendekatan konseptual dan pendekatan undang- undang. Pengumpulan bahan hukum menggunakan teknik studi dokumen. Hasil dari penelitian ini menunjukkan bahwa UU. No. 30 Tahun 1999 serta UU. No. 2 Tahun 2004 secara implisit telah memberikan ruang bagi mediasi online sebagai instrumen alternatif penyelesaian sengketa perselisihan hubungan industrial. Indonesia belum memiliki payung hukum baik formil dan materiil yang mengatur secara "lex specialis" mengenai mediasi online serta kesepakatan tertulis yang dihasilkan dari mediasi online sebagai alternatif penyelesaian sengketa hubungan industrial di masa pandemi COVID-19, belum memiliki kekuatan mengikat secara yuridis, sehingga masih rentan untuk dilanggar oleh para pihak.
\end{abstract}

Kata Kunci: pandemi COVID-19; penyelesaian sengketa; mediasi online 


\section{Pendahuluan}

Luasnya penularan pandemi COVID-19 yang secara langsung menular antar individu melalui droplet atau percikan cairan tubuh yang dikeluarkan melalui sistem pernafasan, khususnya mulut dan hidung. Infeksi dari virus ini menyebabkan penyakit pada organ paru-paru manusia yang dimulai dari gangguan ringan, infeksi sedang hingga pneumonia akut yang dapat menyebabkan kematian. Melihat penyebaran pandemi COVID-19 yang begitu cepat, berbagai Negara di dunia secara sistematis memberlakukan kebijakan "lockdown" dengan cara menutup akses ke suatu Negara serta membatasi kegiatan sosial masyarakat secara ketat. Di Indonesia sendiri sejak dikeluarkannya Keppres Nomor 12 Tahun 2020 Tentang Penetapan Bencana Non-alam, penyebaran Coronavirus Diseases 2019 (COVID-19) sudah berstatus sebagai bencana nasional. (Romlah, Siti, 2020). Oleh sebab itu, proses penyelesaian sengketa secara litigasi maupun non-litigasi yang dilakukan secara langsung dengan menghadirkan para pihak tidak dapat dilaksanakan. Merujuk pada data kemenaker, kasus hubungan industrial yaitu Pemutusan Hubungan Kerja (PHK) menjadi yang terparah selama masa pandemi COVID-19, pekerja formal yang dirumahkan mencapai 1,1 juta orang sementara yang diPHK mencapai 380.000 orang. (Ade Miranti, 2020).

Mediasi berasal dari akar kata bahasa latin "mediare" yang berarti berada di tengah. (I Ketut Artadi \& I Dewa Nyoman Rai Asmara Putra, 2017). Mediasi adalah salah satu bentuk alternatif penyelesaian sengketa non-litigasi yang pelaksanaannya dipimpin oleh seorang dari pihak ketiga yakni "mediator". Presensi mediator dalam mediasi adalah sebagai penengah yang bersifat dalam memberi nasihat yang merujuk pada pemecahan sengketa untuk selanjutnya ditetapkan oleh para pihak bersengketa melalui kesepakatan. Merujuk pada UndangUndang Nomor 2 Tahun 2004 tentang Penyelesaian Perselisihan Hubungan Industrial, khususnya Pasal 1 angka 11 menyatakan mediasi hubungan industrial sebagai berikut:

"Mediasi Hubungan Industrial yang selanjutnya disebut mediasi adalah penyelesaian perselisihan hak, perselisihan kepentingan, perselisihan pemutusan hubungan kerja, dan perselisihan antar serikat pekerja/serikat buruh hanya dalam satu perusahaan melalui musyawarah yang ditengahi oleh seorang atau lebih mediator yang netral." Situasi pandemi COVID -19 saat ini yang membatasi aktivitas manusia secara signifikan, mediasi diharapkan dapat tetap hadir untuk menjawab keresahan para pelaku usaha dan buruh dalam mencari solusi penyelesaian sengketa hubungan industrial di tengah gempuran pandemi namun dilakukan secara online.

Mediasi online sebagai alternatif penyelesaian sengketa hubungan industrial merupakan salah satu wujud nyata fleksibilitas mediasi yang sejalan dengan prinsip pencegahan penularan COVID-19 serta sesuai perkembangan arus teknologi yang begitu pesat serta tidak menuntut kehadiran para pihak secara langsung di suatu tempat, melainkan hanya dengan memasuki online room yang terkoneksi melalui sambungan internet dengan bantuan perangkat komputer. Kebutuhan akan payung hukum yang bersifat "lex specialis" mengenai prosedur mediasi online memiliki signifikansi cukup tinggi untuk segera dihadirkan di tengah-tengah masyarakat, khususnya para pelaku usaha, buruh, serta mediator sehingga dapat melaksanakan mediasi online secara optimal dan tujuan dari mediasi online dapat dicapai. Mediasi online sebagai salah satu alternatif penyelesaian sengketa hubungan industrial pada masa pandemi COVID-19 belum diatur secara eksplisit pada peraturan yuridis yang berlaku di Indonesia, sehingga penulis menemukan masih terdapat kekosongan hukum atau rechts vacuum terkait hal tersebut.

Berdasarkan pemaparan latar belakang diatas, penulis tertarik untuk meneliti secara mendalam penelitian ini dalam bentuk skripsi dengan judul mediasi online sebagai alternatif penyelesaian sengketa hubungan industrial pada masa pandemi covid-19 di indonesia.

Penulis hendak merumuskan beberapa permasalahan yang memiliki relevansi dengan substansi serta judul penelitian hukum ini, guna mendapatkan hasil penelitian yang sesuai dengan sasaran yang dimaksudkan. Merujuk pada latar belakang diatas terdapat beberapa rumusan masalah yang akan penulis angkat dalam penelitian ini, diantaranya: Bagaimana pengaturan mediasi online sebagai alternatif penyelesaian sengketa hubungan industrial pada masa pandemi COVID-19 di Indonesia?; 2. Bagaimana keabsahan hasil mediasi online sebagai alternatif penyelesaian sengketa hubungan industrial pada masa pandemi COVID19 ?

\section{Metode}

Metode penelitian dalam penelitian ini menggunakan metode penelitian hukum normatif yang bertujuan mengkaji substansi kaidah atau norma hukum positif yang mencakup objek 
kajiannya yaitu peraturan perundang-undangan maupun bahan hukum lainnya. (Marzuki, P.M, 2005). Selain itu, penelitian hukum normatif didasarkan pada kompilasi data sekunder dengan penemuan asas-asas hukum dan menelaah struktur dan keberlakuan produk hukum yang terklasifikasi sebagai given data. (Bambang. S,2015).

\section{Hasil Penelitian dan Pembahasan}

\section{Pengaturan Mediasi Online Sebagai Alternatif Penyelesaian Sengketa Hubungan Industrial Pada Masa Pandemi Covid-19 Di Indonesia}

Penyelesaian sengketa hubungan industrial dapat ditempuh melalui dua mekanisme yakni melalui jalur litigasi yang dilakukan dengan cara mengajukan sengketa hubungan industrial ke pengadilan dan jalur non-litigasi yang merupakan penyelesaian sengketa yang dilakukan diluar pengadilan seperti mediasi, negosiasi, konsiliasi, maupun arbitrase. Penyelesaian sengketa hubungan industrial melalui litigasi atau pengadilan kurang diminati oleh banyak pihak. Penyelesaian sengketa secara litigasi baru akan ditempuh ketika berbagai upaya lain (jalur non-litigasi) yang telah diusahakan gagal atau tidak membuahkan hasil sehingga tak khayal jika litigasi dikatakan sebagai ultimum remedium atau jalan terakhir yang dapat ditempuh oleh para pihak dalam menyelesaikan sengketanya. (Azwar. M, 2019). mediasi online menjadi salah satu bentuk dari penyelesaian sengketa non litigatif yang lebih dikenal dengan alternatif penyelesaian sengketa pada perselisihan hubungan industrial.

Secara harfiah pengertian mediasi online dapat dijelaskan dengan cara menguraikan pengertian dari kata "mediasi" dan "online". Mediasi adalah salah satu proses penyelesaian sengketa non litigasi yang dilakukan melalui proses perundingan yang ditempuh oleh para pihak yang terlibat dalam persengketaan dengan dibantu oleh kehadiran "mediator" sebagai pihak ketiga yang bertugas untuk membantu para pihak yang bersengketa untuk mencari dan menghasilkan penyelesaian akhir yang bersifat adil dan dapat diterima oleh para pihak yang bersengketa. (Abdurrasyid, H. Priatna, 2018). Kata online sendiri merupakan akar kata dari bahasa inggris yang dalam kamus besar bahasa Indonesia (KBBI) kata online sering disebut dengan istilah daring yang merupakan singkatan dari dalam jaringan, terhubung melalui jejaring komputer, internet dan sebagainya. (KBBI,

2021).
Dengan demikian, pengertian mediasi online merupakan proses penyelesaian sengketa non litigasi dengan melibatkan presensi pihak ketiga yang kehadirannya telah diterima oleh para pihak untuk mencari dan menghasilkan penyelesaian akhir yang mengakomodir rasa keadilan serta dapat diterima oleh para pihak bersengketa yang dilakukan melalui jaringan yang terhubung dengan internet sehingga mediasi online tidak menuntut kehadiran para pihak secara tatap muka atau nyata. Kehadiran mediasi online yang tidak dapat terlepas dari lajunya perkembangan ilmu pengetahuan dan teknologi pada dasarnya akan meniadakan kesulitankesulitan para pihak dalam menyelesaikan sengketanya khususnya pada saat pandemi Covid-19 yang pada saat ini dalam masa kritis. Proses mediasi yang dilakukan secara online tidak menuntut kehadiran para pihak maupun mediator secara nyata untuk bertatap muka. Mediasi online dapat dikatakan sebagai salah satu konsep futuristik dari proses mediasi atau "futuristic process of mediation" sebagai alternatif penyelesaian sengketa hubungan industrial yang memberi jaminan kepastian hukum bagi para pihak yang sedang menghadapi berbagai sengketa hubungan industrial yang terjadi selama masa pandemi Covid-19.

Pelaksanaan mediasi secara online dalam penyelesaian sengketa hubungan industrial pada hakikatnya juga tidak terlepas dari prinsipprinsip fundamental mediasi sebagaimana yang tertuang dalam skala internasional, yakni:

\section{Kerahasiaan}

Prinsip kerahasiaan diartikan bahwa dalam proses mediasi yang melibatkan para pihak yang bersengketa dan mediator bersifat tertutup dan tidak dapat dipublikasi oleh khalayak umum, sehingga para pihak dapat dengan bebasnya mengungkapkan fakta-fakta hukum maupun pendapatnya.

\section{Sukarela}

Mediasi online dilaksanakan atas dasar iktikad baik dari para pihak demi tercapainya kesepakatan yang dapat secara sukarela diterima oleh kedua belah pihak. Kedua belah pihak memiliki hak dan kewajiban serta kedudukan yang sederajat dalam proses mediasi.

\section{Dapat Dijangkau}

Mediasi online memberikan kemudahan bagi para pihak untuk menjangkau pelaksanaan penyelesaian sengketa sesuai dengan keperluan mereka. Perangkat lunak serta sistem jaringan yang digunakan dalam menunjang pelaksanaan 
mediasi online mengakibatkan mediasi online tidak lagi terpaku dengan ruang dan waktu sehingga para pihak yang bersengketa dapat melakukan mediasi kapan saja dan dimana saja.

\section{Mediator sebagai penuntun mediasi}

Dalam mediasi online, terdapat fitur yang membantu dan menunjang para pihak maupun mediator dalam proses mediasi, yakni hanya dengan memberikan perintah suara para pihak maupun mediator dapat dengan mudahnya mendapatkan data yang tersimpan dalam software karena mediasi online telah difasilitasi oleh fitur assisted voice order. Implementasi penyelesaian sengketa melalui mediasi yang dilakukan secara online di Indonesia pada dasarnya membutuhkan beberapa instrumen pendukung seperti misalnya payung hukum yang digunakan sebagai landasan hukum bagi masyarakat khususnya pekerja yang terlibat dalam hubungan industrial.

Pada umumya penyelesaian sengketa hubungan industrial diluar pengadilan terbagi kedalam dua garis besar yakni penyelesaian sengketa secara bipartit dan penyelesaian perselisihan yang dibantu oleh pihak ketiga atau pihak penengah, sebagaimana penjelasan berikut:

Penyelesaian Sengketa Hubungan Industrial Secara Bipartit

Penyelesaian sengketa hubungan industrial secara bipartit dilakukan dengan proses perundingan berdasarkan musyawarah mufakat oleh para pihak yang bersengketa yakni antara pekerja dan pengusaha yang dilandasi oleh rasa kekeluargaan. Jenis perselisihan yang diselesaikan secara bipartit meliputi perselisihan kepentingan, perselisihan hak, PHK, dan perselisihan antar serikat pekerja dalam satu perusahaan. Penyelesaian bipartit menjadi mekanisme wajib terlebih dahulu untuk diupayakan.

Penyelesaian Sengketa Hubungan Industrial Dengan Bantuan Pihak Ketiga

Apabila setelah perselisihan tersebut dirundingkan oleh para pihak secara bipartit dan ternyata tidak juga tercapai kesepakatan, maka para pihak dapat memilih untuk menyelesaikan perselisihan secara non-litigasi dengan dibantu oleh pihak ketiga melalui mediasi, arbitrase maupun konsiliasi sesuai dengan sengketa dan kewenangan yang diberikan oleh undangundang serta telah disepakati oleh kedua belah pihak.

Pada dasarnya Indonesia telah memiliki aturan hukum yang memberikan landasan untuk dapat dilaksanakannya penyelesaian sengketa alternatif diluar pengadilan. Berbagai metode penyelesaian sengketa alternatif yang terkandung dalam UU No. 30/1999 seperti negosiasi, konsiliasi, mediasi, konsultasi, dan arbitrase pada dasarnya memberikan kebebasan pada para pihak untuk dapat memilih cara penyelesaian sengketa yang terbaik dan sesuai dengan kebutuhan mereka. Undang-Undang Nomor 2 Tahun 2004 yang merupakan payung hukum bagi pelaksanaan resolusi sengketa hubungan industrial yang pada dasarnya hanya mencakup pengaturan mengenai mediasi secara konvensional dan belum mencakup pengaturan mengenai mediasi online. Walaupun demikian, tidak tertutup probabilitas sengketa hubungan industrial untuk ditempuh melalui mediasi online. Pada dasarnya pelaksanaan mediasi online dapat diakomodir dalam menyelesaikan sengketa hubungan industrial yang dapat dilakukan oleh pengusaha dan pekerja yang saling bersengketa.

\section{Keabsahan Hasil Mediasi Online Sebagai Al- ternatif Penyelesaian Sengketa Hubungan Industrial Pada Masa Pandemi Covid-19}

UU No. 30 Tahun 1999 maupun UU No. 2 Tahun 2004 pada dasarnya belum memberikan kedudukan terhadap pelaksanaan mediasi online di Indonesia, namun sebaliknya jika ditelaah lebih dalam, terdapat regulasi yang telah memberikan celah terhadap kedudukan pelaksanaan mediasi secara online. Hal ini terlihat pada Pasal 4 ayat (3) UU No. 30 Tahun 1999 yang menyatakan bahwa:

"Dalam hal disepakati penyelesaian sengketa melalui arbitrase terjadi dalam bentuk pertukaran surat, maka pengiriman teleks, telegram, faksimili, e- mail atau dalam bentuk sarana komunikasi lainnya, wajib disertai dengan suatu catatan penerimaan oleh para pihak".

Sebagaimana ketentuan diatas, pelaksanaan mediasi secara online di Indonesia memiliki kemungkinan untuk dapat dilakukan dengan catatan adanya kesepakatan yang terjadi diantara para pihak yang berselisih. Walaupun ketentuan pasal tersebut telah memberikan peluang bagi Indonesia untuk melaksanakan mediasi secara online namun tetap saja di dalam pelaksanaannya, mediasi online tidak serta merta dapat dilakukan dengan mudah mengingat pelaksanaan maupun kedudukan mediasi online belumlah diatur dalam suatu aturan khusus sehingga tak khayal jika masih begitu banyak permasalahan yang datang silih berganti yang harus dihadapi. Permasalahan tersebut diantaranya 
mengenai dapat atau tidaknya penyelesaian sengketa alternatif untuk didaftarkan pada pengadilan negeri mengingat kesepakatan dari mediasi baru akan mengikat secara yuridis apabila telah didaftarkan pada pengadilan negeri. (Paustinus .S, 2004).

Undang-Undang No. 30 Tahun 1999 maupun Undang-Undang No. 2 Tahun 2004 dapat dikatakan secara implisit telah mengakomodir pengaturan mengenai kedudukan mediasi online sebagai alternatif penyelesaian sengketa hubungan industrial, walaupun demikian kedudukan mediasi online yang menjadi bagian integratif dalam program penyelenggaraan ecourt pada dasarnya telah diakui dalam Peraturan Mahkamah Agung Nomor 1 Tahun 2016 Tentang Prosedur Mediasi di Pengadilan, Pasal 5 ayat (3) Perma No. 1/2016 mengatur bahwa:

"Pertemuan Mediasi dapat dilakukan melalui media komunikasi audio visual jarak jauh yang memungkinkan semua pihak saling melihat dan mendengar secara langsung serta berpartisipasi dalam pertemuan." Dari ketentuan tersebut diatas, maka mediasi online sebagai alternatif penyelesaian sengketa yang pelaksanaannya menggunakan jaringan internet sangat dimungkinkan untuk dilakukan. Jenis mediasi dalam penyelesaian sengketa hubungan industrial ialah mediasi yang dilakukan diluar pengadilan, dimana mediasi tersebut dilakukan sebelum salah satu pihak mengajukan gugatan pada Pengadilan Hubungan Industrial sehingga apabila mediasi tersebut tidak dapat menemukan titik terang, maka kemudian gugatan dapat diajukan.(Ugo \& Pujiyo, 2012). Sedangkan mediasi yang dimaksud dalam Perma No. 1/2016 ialah mediasi yang dilakukan didalam pengadilan yang berarti bahwa mediasi tersebut dilakukan setelah gugatan tersebut diajukan ke pengadilan oleh salah satu pihak, dimana hakim pemeriksa perkara yang memerintahkan kedua belah pihak untuk menempuh mediasi.

Kesepakatan perdamaian sebagai produk dari mediasi tidaklah memiliki kekuatan hukum mengikat tanpa dikuatkan hingga menjadi akta perdamaian terlepas itu merupakan hasil mediasi yang dilakukan diluar maupun didalam pengadilan. Apabila sengketa hubungan industrial melalui mediasi mencapai suatu kesepakatan maka kemudian akan dituangkan kedalam perjanjian bersama yang ditandatangani oleh para pihak serta disaksikan oleh mediator. Akta perdamaian atau acta van dading harus didaftarkan pada Pengadilan Hubungan Industrial pada Pengadilan Negeri sesuai dengan yurisdiksi dibuatnya perjanjian bersama. Perjanjian perdamaian hasil mediasi yang telah dikukuhkan dan statusnya menjadi akta perdamaian (akta van dading) memiliki kekuatan yang sama seperti halnya putusan pengadilan yang berkekuatan hukum tetap. (Dedy .M, 2019). Prosedur tersebut telah tertuang sebagaimana dimaksud dalam ketentuan Pasal 13 ayat (1) UU No. 2/2004. Ketentuan Pasal 13 ayat (1) UU No. 2/2004 pada dasarnya menuntut kehadiran para pihak secara langsung dalam proses mediasi.

Perma tersebut tidak mengatur ketentuan mengenai kekuatan hukum hasil mediasi apabila para pihak melakukan mediasi secara online atau melalui komunikasi audio visual jarak jauh. Walaupun ketentuan di dalam Perma No. 1/2016 memberikan celah untuk dapat dilakukannya mediasi online namun pada kenyataannya pelaksanaan mediasi online masih menimbulkan berbagai pertanyaan dan sulit untuk dieksekusi mengingat belum adanya peraturan pelaksanaan lebih lanjut mengenai mediasi online, terpenting lagi landasan hukum pelaksanaan mediasi online pada dasarnya akan berpengaruh pada keabsahan hasil mediasi online tersebut. Tidak adanya aturan yang secara khusus mengakomodir pelaksanaan mediasi online menjadi permasalahan yang sangat urgen untuk segera diatasi mengingat pada saat ini pandemi covid-19 hampir melanda seluruh belahan negara didunia yang mengharuskan aktivitas berkumpul atau bertatap muka secara langsung sangat dibatasi.

\section{Simpulan}

Pengaturan Mediasi online sebagai alternatif penyelesaian sengketa secara lex generalis telah diatur pada Undang-Undang No. 30 Tahun 1999 tentang Arbitrase dan Alternatif Penyelesaian Sengketa serta Undang-Undang No. 2 Tahun

2004 Tentang Penyelesaian Perselisihan Hubungan Industrial. Kedua aturan tersebut memungkinkan pelaksanaan mediasi online sebagai salah satu bentuk alternatif penyelesaian sengketa hubungan industrial. Namun, guna memperkuat kedudukan mediasi online secara yuridis, diperlukan adanya pengaturan yang secara lex specialis mengatur kedudukan serta pelaksanaan mediasi online yang dilakukan diluar pengadilan, khususnya dalam perselisihan hubungan industrial.

Keabsahan hasil mediasi online sebagai alternatif penyelesaian sengketa hubungan industrial di masa pandemi COVID-19 yang berbentuk kesepakatan tertulis belum dapat dikatakan mengikat secara yuridis. Hal tersebut diakibatkan belum adanya payung hukum positif di Indonesia yang memberikan legalitas secara 
spesifik terhadap hasil mediasi online, sehingga sifat binding dari kesepakatan yang dihasilkan dari mediasi online cukup lemah sehingga rentan untuk dilanggar oleh para pihak.

\section{Daftar Pustaka}

Abdurrasyid, H, P, (2018). Arbitrase dan Alternatif Penyelesaian Sengketa (APS) Suatu Pengantar. Jakarta: Fikahati Aneska.

Artadi, I, K., Putra, I, D, R, N, A. (2017). Anatomi Kontrak Berdasarkan Hukum Perjanjian. Denpasar: Udayana University Press.

Azwar, M. (2019). Prospek Penerapan Online Dispute Resolution dalam Upaya Penyelesaian Sengketa Bisnis di Indonesia. Media Iuris. 2(2).

KBBI, URL: http://kbbi.kemdikbud.go.id/entri/ daring, diakses pada tanggal25 Januari 2021.

Marzuki, P, M. (2005). Metode Penelitian Hukum. Jakarta: Kencana.

Miranti, A. (2020). Imbas Corona, Lebih Dari 3,5 Juta Pekerja Kena PHK dan Dirumahkan, URL: https:// money.kompas.com/ $\mathrm{read} / 2020 / 08 / 04 / 163900726 /$ imbascorona-lebih-dari- 3-5-juta-pekerjakena-phk-dan-dirumahkan?page $=$ all diakses pada; 22 Januari 2021, pukul 14.20 WITA.

Mulyana, M. (2019). Kekuatan Hukum Hasil Mediasi di Luar Pengadilan Menurut Hukum Positif. Wawasan Yuridika 3 (2).

Romlah, S. (2020). Covid-19 dan Dampaknya Terhadap Buruh Indonesia. Adalah: Buletin Hukum dan Keadilan. Vol. 4, No. 1.

Sunggono, B. (2015). Metodologi Penelitian Hukum. Jakarta: Rajawali Press.

Siburian, P. (2004). Arbitrase Online. Jakarta: Djambatan.

Ugo., Pujiyo. (2012). Hukum Acara Penyelesaian Hubungan Industrial. Jakarta: Sinar Grafika. 